\title{
Annual cycle of particle size fractions and phytoplankton biomass in the northern Baltic proper
}

\author{
Mati Kahru, Ellen Kaasik, Aina Leeben \\ Institute of Ecology and Marine Research, Paldiski Rd. 1, Tallinn 200031, Estonia, USSR
}

\begin{abstract}
A large data set of particle concentrations in the range 1 to $1000 \mu \mathrm{m}$, chlorophyll $a$, and associated measurements from the surface waters of the northern Baltic proper during 1985 to 1989 was analyzed to construct spatially and temporally averaged annual time curves of particle size fractions and phytoplankton biomass. Chlorophyll a concentration was well correlated with the 28-73 $\mu$ m size fraction and had 2 seasonal peaks: in April-May, corresponding to the diatom spring bloom, and in August, corresponding to the late-summer bloom of blue-green algae. The 2 maxima were separated by the early summer minimum when the 1-10 $\mu \mathrm{m}$ particle fractions corresponding to a mixed assemblage of small phytoplankton and microheterotrophs reached their maxima. The largest particles (163-1000 $\mu \mathrm{m})$, corresponding to smaller mesozooplankton, reached their maximum in July-August before the bluegreen maximum. Automated particle counting is well suited for routine monitoring of pelagic systems as it reveals all major shifts in the planktonic community.
\end{abstract}

\section{INTRODUCTION}

Due to the dramatically increased nutrient loadings during recent decades (Larsson et al. 1985), the ecosystems of the Baltic Sea are under pressure to adjust in response to the changing environment. However, in contrast to benthic and near-shore ecosystems, where such changes have been clearly documented (Elmgren 1989), analogous effects in the pelagic systems have been difficult to demonstrate. One reason is that data from off-shore areas are scarce compared to coastal areas. Another obstacle to unequivocally detecting trends is the high inherent temporal and spatial variability of the Baltic pelagic ecosystem. It has been estimated that temporal variability in chlorophyll concentration during the productive season causes average errors of over $100 \%$ in a monitoring point sample whereas the mesoscale spatial variability (e.g. eddies and fronts) adds another $100 \%$ error (Kahru \& Aitsam 1985, Kahru et al. 1987). Reliable time curves of the annual development of the pelagic communities in the Baltic are needed, e.g. for modeling of the long-term development of the ecosystem (see Wulff 1988), as well as for detecting trends.

In this paper we try to establish averaged annual time curves for some characteristics of the pelagic system in the northern Baltic proper based on a large set of automated measurements of particle size fractions, chlorophyll a concentration ( $\mathrm{chl} a)$, and associated measurements. Statistical analysis of the variability structure of these parameters will be reported elsewhere.

In offshore areas the influence of resuspension and land-based runoff are expected to be minimal, hence most of the particles measured are of biological origin. The size of a planktonic particle is itself an ecologically important parameter, as it often determines its specific growth rate (Fenchel 1974), its fate in the food chain (Platt \& Denman 1978), and its ability to remain suspended (Malone 1980). Hence seasonal time curves of the particle size fractions may give some insight into the functioning of the pelagic ecosystem.

\section{MATERIALS AND METHODS}

Data collection. Measurements were made from RV 'Arnold Veimer' cruises 6, 8, 10, 11, 13, 14, 18, 19, 20, 23, 30, 31, 32 between 1985 and 1989 in the 'on-track' mode while the ship was steaming along a straight 
course at a constant speed. Underway shipboard measurements of particle concentrations, chlorophyll in vivo fluorescence, temperature and salinity were obtained from $5 \mathrm{~m}$ depth (Kahru et al. 1989, Kahru \& Nômmann 1990). The sampling system consisted of an on-line Hiac-Royco PC-320 particle counter, a Turner Designs 10-005R flow-through fluorometer, and a thermosalinograph measuring water temperature and conductivity.

The time interval between the registration of integrated particle counts and other parameters was set at $1 \mathrm{~min}$ and corresponded to a space interval of 200 to $400 \mathrm{~m}$.

The Hiac-Royco particle counter (Pugh 1978) with 2 sensors registered particles with equivalent spherical diameter from 1 to $1000 \mu \mathrm{m}$ in 12 channels (Table 1). The sensors operate on the principle of light blockage. The counting time was $10 \mathrm{~s}$ during which 1 and $170 \mathrm{~cm}^{3}$ of seawater, respectively, passed through the 2 sensors. Concentrations in the channels (size classes) are designated as Ch1 to Ch12. Ch6 was discarded from the analysis as it was mostly covered by $\mathrm{Ch} 7$ and Ch8 of the other sensor, but because of the very small flow rate through the small sensor, the number of counts in it was too low to be reliable.

The on-track measurements were supplemented with quantitative samples of phyto- and zooplankton abundance to establish links between the particle size fractions and plankton species as well as measurements of the extracted chl (Edler 1979). The fluorescence was converted to chlorophyll $a$ by calibration against extracted chl separately for each cruise (correlation coefficients, $r=0.73$ to 0.99 ).

Data analysis. The usual way of representing particle data is to express them as volume concentrations (Sheldon et al. 1972), but as particles can seldom be considered spherical, the conversion of surface area measured by the Hiac-Royco sensors to volume was not

Table 1. Channel settings for the Hiac-Royco Model PC-320 particle counter in equivalent spherical diameters

\begin{tabular}{|cccl}
\hline Sensor & Channel $\begin{array}{c}\text { Diameter } \\
(\mu \mathrm{m})\end{array}$ & \multicolumn{1}{c|}{ Dominant particles } \\
\hline CMH-60 & 1 & $1-2$ & Bacteria, picoplankton \\
& 2 & $2-4$ & Picoplankton \\
& 3 & $4-6$ & Nanoplankton \\
& 4 & $6-10$ & Nanoplankton \\
& 5 & $10-20$ & Nanoplankton \\
& 6 & $20-60$ & Not used \\
E-1000 & 7 & $28-42$ & Diatoms, blue-greens \\
& 8 & $42-73$ & Diatoms, dinoflagellates \\
& 9 & $73-105$ & Diatom chains, dinoflagellates \\
& 10 & $105-163$ & Large protozooplankton \\
& 11 & $163-305$ & Copepodites, nauplii \\
& 12 & $305-1000$ & Copepods \\
\hline
\end{tabular}

pursued. Moreover, the activity of organisms is roughly proportional to their surface area and not to their volume (Fenchel 1974, Platt \& Denman 1978, Kiørboe et al. 1990). Hence, as a measure of the integral particle concentration, we use the total particulate surface area (PSA) in the range 1 to $1000 \mu \mathrm{m}$. Total PSA is calculated by multiplying the channel concentrations by the respective average surface area, and summing over all channels. As a measure of the relative importance of a size fraction, the percent contribution of the fraction to the total PSA is used.

The on-track data with 200 to $400 \mathrm{~m}$ interval were averaged over $10 \mathrm{~km}$ segments of track. Hence, each sample considered here is an average over $10 \mathrm{~km}$, i.e., depending on the ship's speed, 25 to 50 individual measurements. This was found to be a suitable averaging scale to represent the mesoscale structure (Kahru et al. 1987).

From the on-track measurements covering the whole Baltic (with the exception of the Gulf of Bothnia), data from the most frequently visited northern Baltic proper (north of $58^{\circ} \mathrm{N}$ ) and the western Gulf of Finland (west of $24^{\circ} \mathrm{E}$ ) were extracted (Fig. 1). Data from all cruises between 1985 and 1989 were pooled. The combined study period covered most of the year with the exception of the winter period (January to March). Samples over several years were combined according to their corresponding Julian day. These samples were further pooled into $10 \mathrm{~d}$ periods from the beginning of the year (e.g. 1 to 10 January is period 1, etc.). The total number of $10 \mathrm{~km}$ averaged samples was 790 and most of the $10 \mathrm{~d}$ periods had between 40 and 60 samples (Fig. 2). Because of occasional malfunctioning of the small particle sensor, the actual number of samples is somewhat smaller for the small size fractions (Ch1 to Ch5) with resulting gaps in the coverage of the annual cycle.

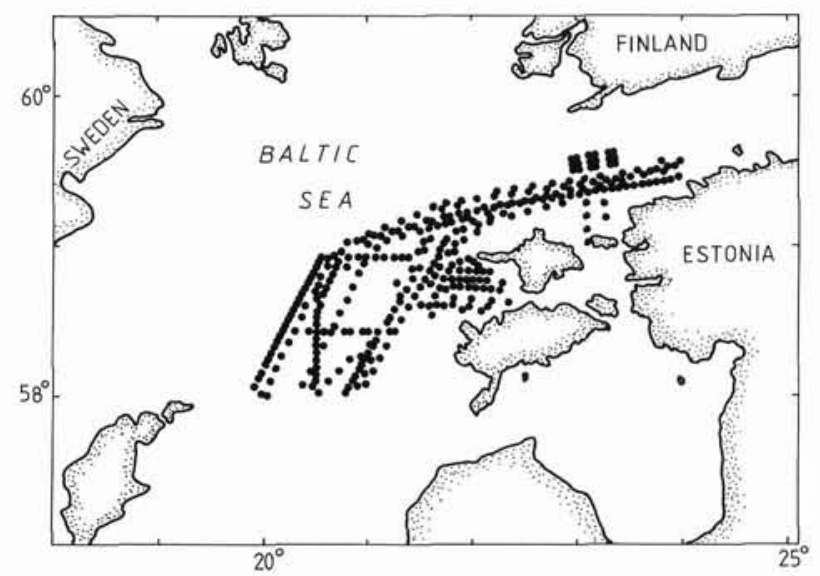

Fig. 1. Spatial distribution of samples in the northern Baltic proper. Each sample (dot) is an average over a $10 \mathrm{~km}$ transect ( 25 to 50 measurements) at $5 \mathrm{~m}$ depth 


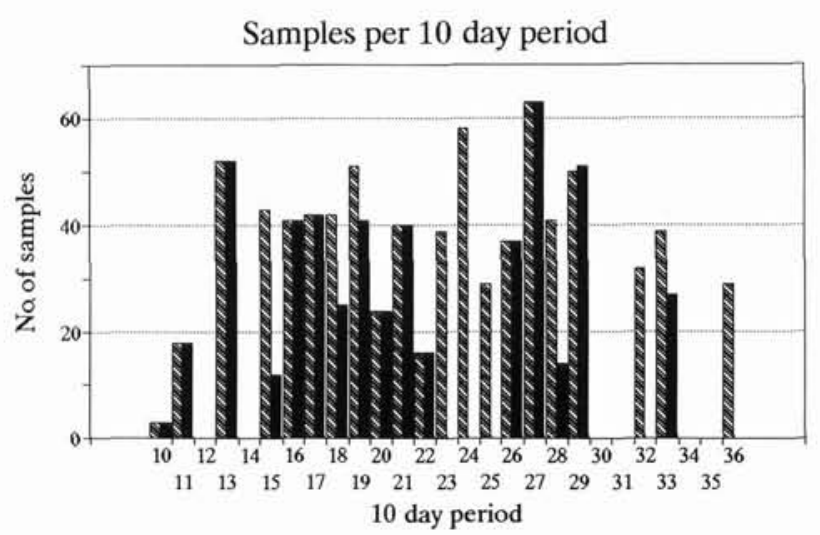

Fig 2. Temporal distribution of the pooled particle samples from 1985 to 1989 in $10 \mathrm{~d}$ periods. The total number of samples is 790 for Ch7 to Ch12 (28-1000 $\mu \mathrm{m}$, left bar) and 506 for Ch1 to Ch5 (1-20 $\mu \mathrm{m}$, right bar)

\section{RESULTS}

The annual course in sea-surface temperature (Fig. 3) gives at the same time a qualitative time curve of changes in water column stratification: high surface temperature indicates a shallow upper layer and vice versa. Only during the commencement of the spring bloom (up to $10 \mathrm{~d}$ period 13 in Fig. 3) did slight salinity stratification provide vertical stability of the water column, when the water temperature was still below the point (about $2.4^{\circ} \mathrm{C}$ ) at which maximum density is attained.

The time curves of the 2 integral parameters - chl a concentration and the total particulate surface area (PSA) in the diameter range 1 to $1000 \mu \mathrm{m}$ - both show 2 maxima (Fig. 4) corresponding respectively to the diatom spring bloom (10 d'periods 11 to 13, April-May) and to the late-summer bloom of blue-green algae (10 d periods 23 to 28, August-September). Chl increased faster in the beginning phase of the spring bloom while total PSA accumulated slower. The earlysummer minimum (10 d periods 17 to 20, June-July) was more pronounced in chl than in total PSA. Chl values decreased almost to pre-spring-bloom values. The vigorous increase in the small particle fractions (Fig. 5A,B) and the more gradual increase in the largest particle fractions (Fig. 5E) to some extent compensate for the drastic loss of the 28 to $105 \mu \mathrm{m}$ size range (Fig. $5 \mathrm{C}, \mathrm{D})$. However, the compensation is only partial as a considerable fraction of the particulate matter sediments out of the surface layer with the decline of the diatom bloom (Leppänen 1988).

It must be noted that due to averaging over several years, some features may appear prolonged compared to the time that they actually last in a particular year. For example, the spring bloom on each of the 2 years included $(1985,1986)$ was shorter than the averaged

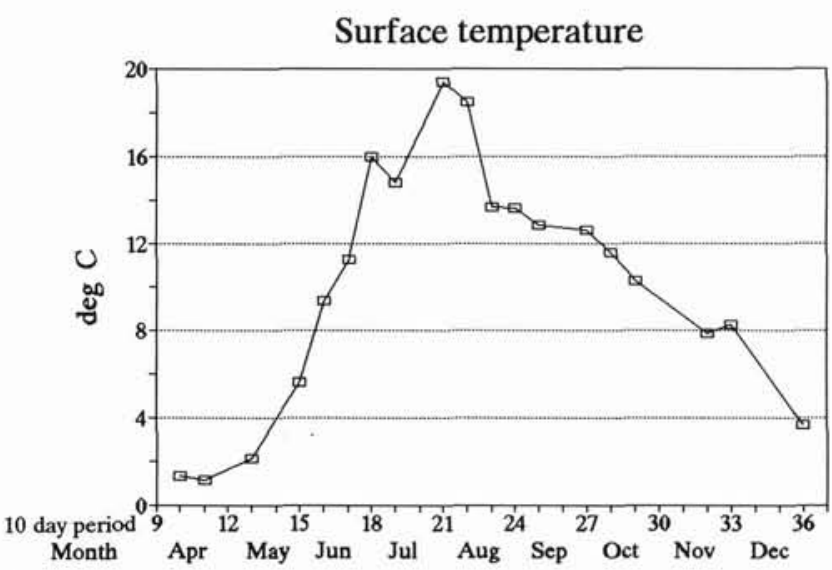

Fig. 3. Annual time curve of temperature versus $10 \mathrm{~d}$ periods and months

Chl a

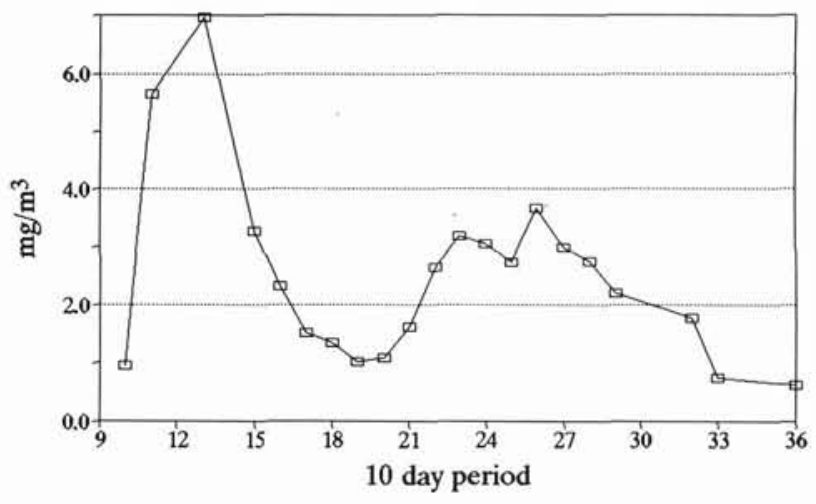

Total particulate surface area

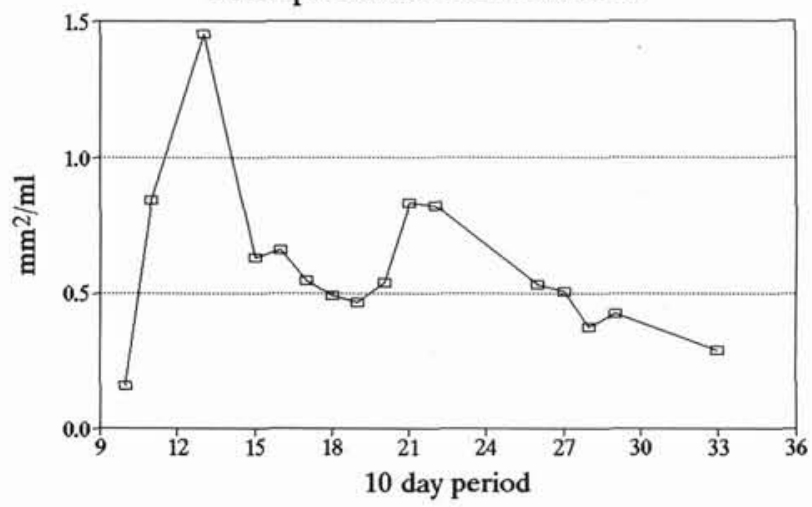

Fig. 4. Annual time curves of chlorophyll $a$ and total particulate surface area in the $1-1000 \mu \mathrm{m}$ size range

curve. Another result of the $10 \mathrm{~d}$ and yearly averaging is that the maxima become lower and the minima higher.

Apart from the general increase-decrease of the integral phytoplankton biomass or particle concentration, the contribution of a size fraction to the total PSA should give an estimate of the changing share of that size fraction in the community metabolism. 

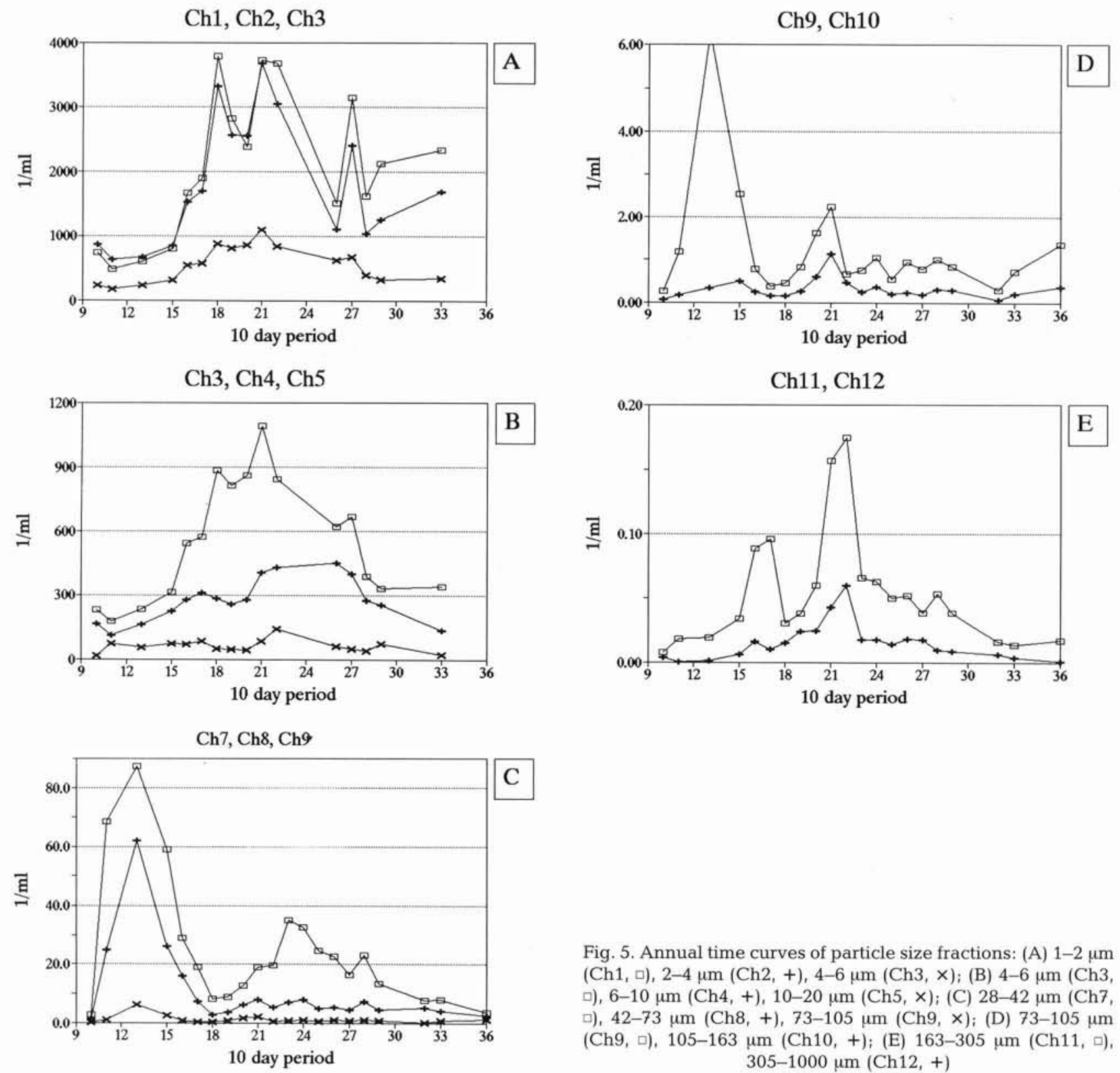

Fig. 5. Annual time curves of particle size fractions: (A) 1-2 $\mu \mathrm{m}$

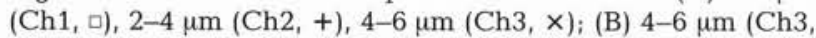
ㅁ), 6-10 $\mu \mathrm{m}(\mathrm{Ch} 4,+), 10-20 \mu \mathrm{m}(\mathrm{Ch} 5, \times)$; (C) 28-42 $\mu \mathrm{m}$ (Ch7, ㅁ), 42-73 $\mu \mathrm{m}(\mathrm{Ch} 8,+), 73-105 \mu \mathrm{m}(\mathrm{Ch} 9, \times)$; (D) 73-105 $\mu \mathrm{m}$

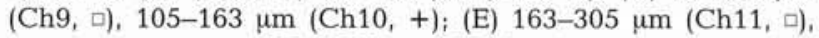
305-1000 $\mu \mathrm{m}(\mathrm{Ch} 12,+)$

The smallest size fractions (Fig. 6A,B) represented a high percentage of the total PSA before the start of the massive diatom bloom, and increased again during the decline of the diatom bloom. For example, in $10 \mathrm{~d}$ periods 10 (April) and 18 (June) the $1-10 \mu \mathrm{m}$ size fraction made up respectively 52 and $50.5 \%$ of total PSA in the range 1 to $1000 \mu \mathrm{m}$ (Fig. 7), and its percentage dropped to $5 \%$ during the peak of the spring bloom (beginning of May). The concentration of the largest particle size fractions (Fig. 5E) as well as their contribution to the total PSA (Fig. 6D) showed a general maximum in August $(163-1000 \mu \mathrm{m})$ or another maximum after the diatom spring bloom (163-305 $\mu \mathrm{m})$. The major seasonal changes in the plankton community are

shown by the time curves of the combined covarying size fractions (Fig. 7). The 28-105 $\mu \mathrm{m}$ size fraction (Ch7 to Ch9) made up $83 \%$ of the total PSA during the diatom spring bloom. In strong diatom blooms its share may locally reach $95 \%$.

In the medium to large size fractions ( $\mathrm{Ch} 7$ to $\mathrm{Ch} 12$ ), the first concentration maximum is attained later, the bigger the mean size of the particles is (Fig. 8). Because of the coarse resolution in time ( $10 \mathrm{~d}$ period), the difference in the $\mathrm{Ch} 7$ to $\mathrm{Ch} 9$ size fractions is not resolved in this figure. A more detailed examination shows that even within $\mathrm{Ch} 7$ to $\mathrm{Ch} 9$ the maximal values in the bigger size classes occurred definitely later. This is also true for the percent contributions where 

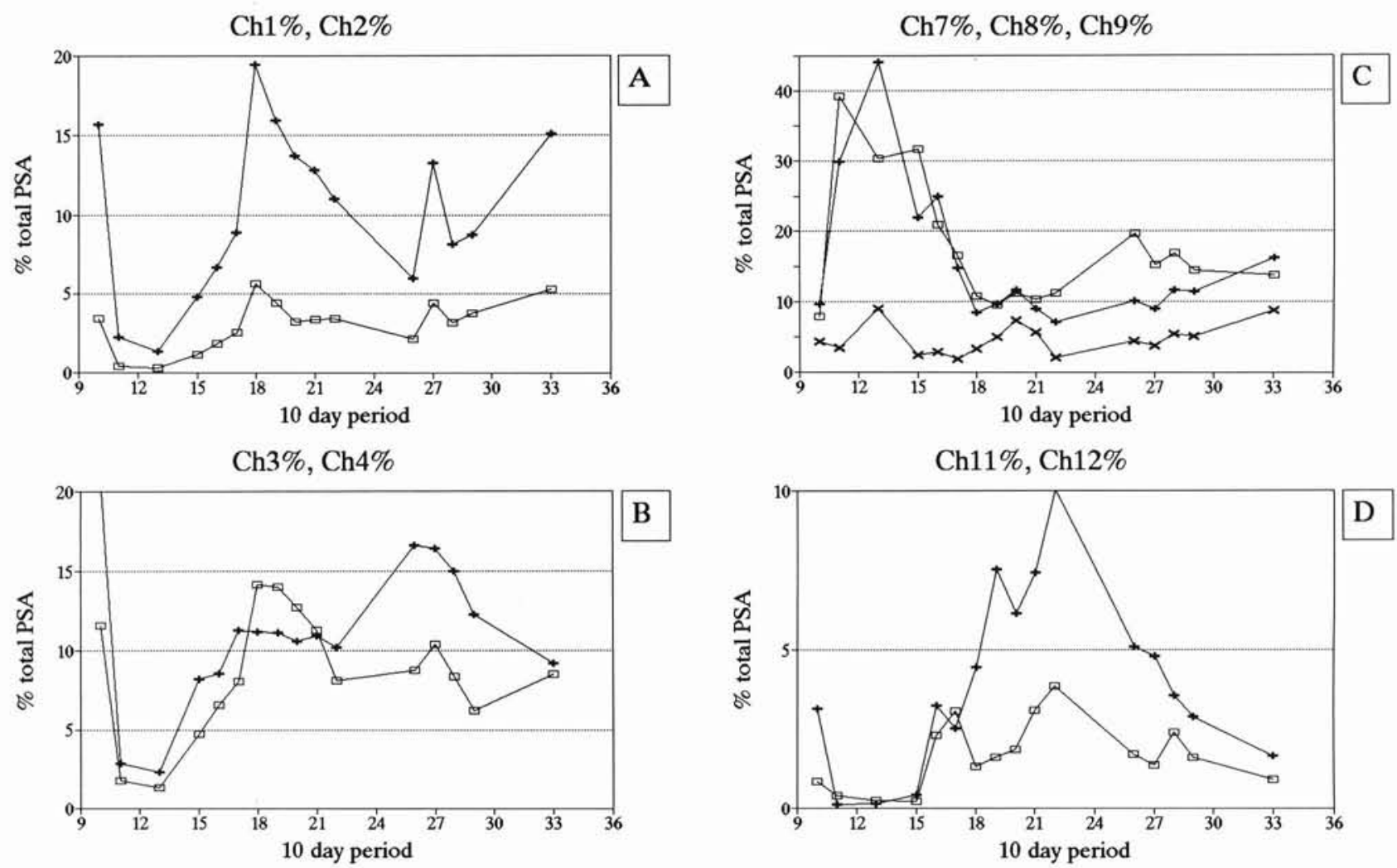

Fig. 6. Annual time curves of the percent contribution of a size fraction to the total particulate surface area: (A) $1-2 \mu \mathrm{m}(\mathrm{Ch} 1 \%$, $\square$ ),

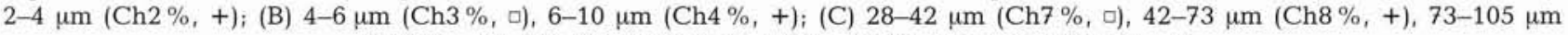
$(\mathrm{Ch} 9 \%, \times)_{i}$ (D) 163-305 $\mu \mathrm{m}(\mathrm{Ch} 11 \%$, , $), 305-1000 \mu \mathrm{m}(\mathrm{Ch} 12 \%,+)$

the maximum of $\mathrm{Ch} 7$ preceded the maxima of $\mathrm{Ch} 8$ and Ch9 (Fig. 6C).

In order to find covarying groups of variables, the $10 \mathrm{~d}$ averaged data set was submitted to principal component analysis (see e.g. Mayzaud et al. 1984). The first set of data included all the size fractions and chl (Table 2).

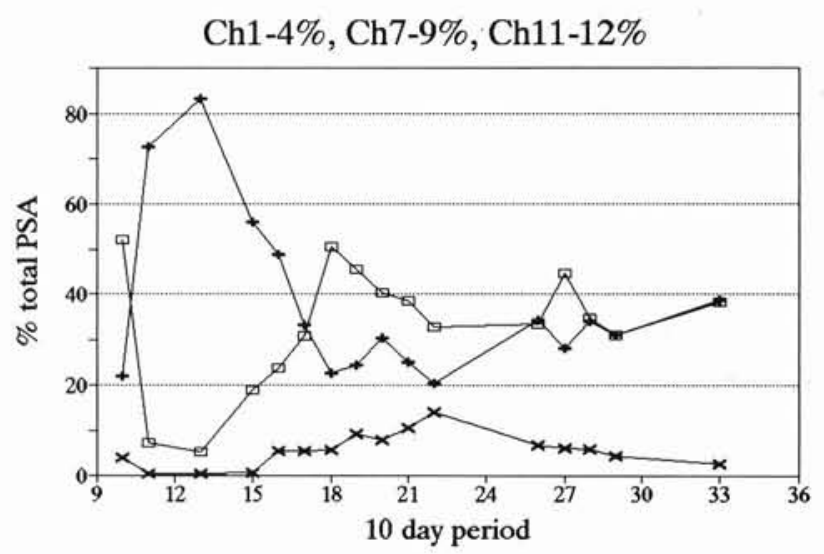

Fig. 7. Annual time curves of the combined contributions to the total particulate surface area: $1-10 \mu \mathrm{m}(\mathrm{Ch} 1$ to $\mathrm{Ch} 4 \%, \square)$; 28-105 $\mu \mathrm{m}$ (Ch7 to Ch9\%, +); 163-1000 $\mu \mathrm{m}(\mathrm{Ch} 11$ to Ch12 \%, x)
Nearly half of the variance was described by the first component with positive input from $\mathrm{Ch} 1$ to $\mathrm{Ch} 3$, and negative input from $\mathrm{Ch} 7$ to $\mathrm{Ch} 9$ and chl. The second component represented mostly the positive contributions from chl and $\mathrm{Ch} 7$ to $\mathrm{Ch} 9$. In the second data set with only $\mathrm{Ch} 7$ to $\mathrm{Ch} 12$ and chl, the first principal component ( $48 \%$ of variance) had positive contributions from chl and $\mathrm{Ch} 7$ to $\mathrm{Ch} 9$, and the second component was associated with the large particles (Table 3).

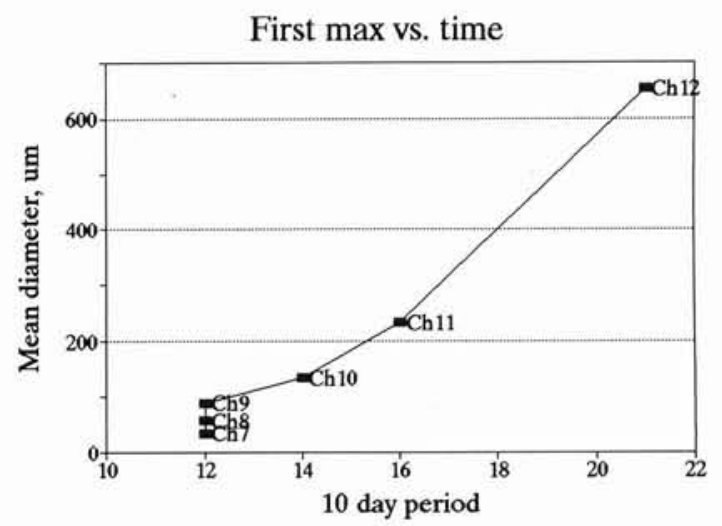

Fig. 8. Relationship between time of first concentration maximum and mean particle size (from $\mathrm{Ch} 7$ to $\mathrm{Ch} 12$ ) 
Table 2. First 3 principal components of the particle size fractions $\mathrm{Ch} 1$ and $\mathrm{Ch} 12$, and chl. Constituents with positive and negative contributions are listed in the order of importance

\begin{tabular}{|c|c|c|c|}
\hline $\begin{array}{l}\text { Component } \\
\text { no. }\end{array}$ & $\begin{array}{c}\% \text { of } \\
\text { variance }\end{array}$ & $\begin{array}{l}\text { Cumulative } \\
\text { variance }\end{array}$ & Major constituents \\
\hline 1 & 43.3 & 43.3 & $\begin{array}{l}+ \text { Ch } 1,+ \text { Ch } 2,+ \text { Ch } 3 \\
- \text { Ch8, }- \text { Ch } 7,- \text { Ch } 1,- \text { Ch } 9\end{array}$ \\
\hline 2 & 23.8 & 67.1 & + chl,+ Ch9, + Ch7, + Ch8 \\
\hline 3 & 13.6 & 80.6 & - Ch5, - Ch4 + + Ch10 \\
\hline
\end{tabular}

Table 3. First 3 principal components of the particle size fractions $\mathrm{Ch} 7$ to $\mathrm{Ch} 12$ and chl. Constituents with positive and negative contributions are listed in the order of importance

\begin{tabular}{|cccc|}
\hline $\begin{array}{c}\text { Component } \\
\text { no. }\end{array}$ & $\begin{array}{c}\% \text { of } \\
\text { variance }\end{array}$ & $\begin{array}{c}\text { Cumulative } \\
\text { percentage }\end{array}$ & Major constituents \\
\hline 1 & 47.6 & 47.6 & + Ch8, + Ch7, + chl, + Ch9 \\
2 & 30.4 & 78.0 & + Ch11, + Ch12, + Ch10 \\
3 & 13.6 & 91.6 & - Ch10 \\
\hline
\end{tabular}

\section{DISCUSSION}

One of the major problems in dealing with particle size data is the interpretation of the particles in terms of ecologically more meaningful components. As shown by Lahdes \& Leppänen (1988) in the same area, the particulate matter in the surface water is predominantly autochthonous, originating from plankton organisms. Although detritus particles may be significant, especially during the declining phase of a phytoplankton bloom, due to sedimentation and other processes removing detritus from the near-surface layer, the majority of particles presumably represent plankton organisms. Indirect proof for that is provided by the frequently high correlations between certain particle size fractions and chl fluorescence while direct proof has been provided by microscopic analyses.

The dominant types of particles in each size fraction were included in Table 1. Although the majority of plankto-bacteria are smaller than $1 \mu \mathrm{m}$ (Lahdes et al. 1988), according to other results (Larsson \& Hagström 1982) $40 \%$ of the bacteria are retained by a $1 \mu \mathrm{m}$ filter. We believe that the 1 to $2 \mu \mathrm{m}$ fraction (Ch1) consisted mostly of large free-living bacteria and small autotrophic cells. The general dynamics of the small fraction corresponds well with the known seasonal development of bacterial biomass from the northern Baltic (Larsson \& Hagström 1982, Kuparinen et al. 1984, Lahdes et al. 1988). The time curves of the other $<10 \mu \mathrm{m}$ fractions showed quite similar changes. The shift towards the dominance of nanoplankton during summer is well known (Hobro 1979). From the results of Huttunen \& Kuparinen (1986) we may guess that among the dominant organisms in our size fractions are the following: Ch1 (1-2 $\mu \mathrm{m})$ - Nannochloropsis sp. (mean diameter $1.5 \mu \mathrm{m}) ;$ Ch2 $(2-4 \mu \mathrm{m})$ - Nannochloropsis sp., Chrysochromulina spp., flagellates; Ch3 to Ch4 $(4-10 \mu \mathrm{m})$ - Chrysochromulina spp., Cryptomonadales, flagellates. The dominance of Pyramimonas sp. and Cryptomonas spp. in the Ch4 to Ch5 fraction during the spring bloom has been confirmed (Kahru \& Nômmann 1990). 'Flagellates' combine both autotrophic and heterotrophic plankters.

The easiest to interpret are the Ch7 and Ch8 (28-73 $\mu \mathrm{m})$ fractions which during the diatom spring bloom predominantly represent the dominant diatom species (e.g. Achnanthes taeniata, Chaetoceros spp.) (Kahru \& Nômmann 1990), and during the late-summer bluegreens maximum represent the dominant blue-green algae (e.g. Aphanizomenon flos-aquae) (Kahru et al. 1989). The shift towards bigger particles (from $\mathrm{Ch} 7$ to Ch9) during the vernal phytoplankton succession is sometimes caused by the increasing size of A. taeniata chains (Kahru et al. 1986). During the late-summer blue-green bloom, Ch9 $(73-105 \mu \mathrm{m})$ has been found to be well correlated with the abundance of the dinoflagellate Dinophysis norvegica (Kahru et al. 1989). Ch10 $(105$ to $163 \mu \mathrm{m})$ may be correlated with larger protozooplankton or small metazooplankton but no evidence has been acquired. Ch11 and Ch12 represent smaller zooplankton (Kahru et al. 1989); Ch11 (165-305 $\mu \mathrm{m})$ is correlated with copepodites, copepod nauplii and eggs, and large protozoans; Ch12 (305-1000 $\mu \mathrm{m})$ with copepods and smaller cladocerans.

The annual cycle of the Baltic pelagic community has been extensively studied in several coastal areas of the Baltic Sea, i.e. the Kiel Bight (Smetacek et al.1984), the Askö-Landsort (Hobro 1979, Larsson \& Hagström 1982, Jansson et al. 1984), and the Tvärminne areas (Niemi 1975, Forsskahl et al. 1982, Kuparinen et al.1984, Huttunen \& Kuparinen 1986, Kononen \& Niemi 1986). The last area borders with that under study in this paper.

The general features of the annual dynamics as revealed here are similar to results obtained in the studies mentioned above. These results together support the emerging general concept that in a stratified, oligotrophic water column small phytoplankton cells and the 'microbial loop' (Azam et al. 1983) type of food chain dominate whereas in case of stronger vertical turbulence large phytoplankton cells (diatoms) and the 'classical' (Steele 1974) type of food chain prevail (Cushing 1989, Kiørboe et al. 1990).

However, in contradiction to that concept is the observation by Kahru \& Nômmann (1990) that the wellknown, massive diatom bloom is preceded by a short period with initial growth of unidentified small-sized 
(1-4 $\mu \mathrm{m})$ phytoplankton which are then outgrown by diatoms.

The coincidence in the peaks of summer nanoplankton dominance and bacterial production supports the concept of their trophic relationship (Larsson \& Hagström 1982).

The seasonal shift in the maximum of $\mathrm{Ch} 7$ to $\mathrm{Ch} 12$ resembles the cascade of organic matter from smaller to larger particles along the 'classical' foodchain (Platt \& Denman 1978).

The 2 maxima in the annual curve of Ch11 (Fig. 5E) seem to be related to the biology of zooplankton and not artifacts. The first maximum (10 d periods 16 and 17, 31 May to 19 June) occurred after the decline of the spring bloom, and the second ( $10 \mathrm{~d}$ periods 21 and 22 , 20 July to 9 August) preceded the peak in the bluegreens. The second maximum is also prominent in Ch12 and corresponds well to the known zooplankton maximum in this area (Kuparinen et al. 1984).

Because of the low overwintering zooplankton population in the Baltic Sea, the 'classical' food chain is not effective and the bulk of the organic matter produced by the diatom spring bloom sediments out of the upper layer (Forsskahl et al. 1982, Jansson et al. 1984, Leppänen 1988). Another characteristic feature of the Baltic ecosystem is the late-summer bloom of the nitrogenfixing blue-green algae (e.g. Jansson et al. 1984), also evident in the particle data.

The averaged time curves of the particle concentrations, showing quite different behavior depending on the size fraction, clearly reveal the major shifts in the structure and functioning of the planktonic system. As data from offshore areas are difficult and expensive to obtain with the required time and space resolution, automated particle and fluorescence measurements that can be obtained semi-automatically with a high resolution present an attractive compliment to more elaborate biological analyses.

Acknowledgements. Thanks are due to the scientific party and staff of RV 'Arnold Veimer' for assistance at sea. S. Nômmann provided valuable help in operating the system. J. Sildam helped with transferring the thermosalinograph data; T. Raid and T. Nôges provided the zooplankton data.

\section{LITERATURE CITED}

Azam, F., Fenchel, T., Field, J. G., Gray, J. S., Meyer-Reil, L.A., Thingstad, F. (1983). The ecological role of water column microbes in the sea. Mar. Ecol. Prog. Ser. 10: 257-263

Cushing, D. H. (1989). A difference in structure between ecosystems in strongly stratified waters and those that are only weakly stratified. J. Plankton Res. 11: 1-13

Edler, L. (1979). Recommendations for marie biological studies in the Baltic Sea. The Baltic Marine Biologists 5, p. 1-38

Elmgren, R. (1989). Man's impact on the ecosystem of the
Baltic Sea: energy flows today and at the turn of the century. Ambio 18: 326-332

Fenchel, T. (1974). Intrinsic rate of natural increase: the relationship with body size. Oecologica (Berl.) 14: 317-326

Forsskahl, M., Laakoonen, A., Leppänen, J.-M, Niemi, A., Sundberg, A., Tamelander, G. (1982). Seasonal cycle of production and sedimentation of organic matter at the entrance to the Gulf of Finland. Neth. J. Sea Res. 16: 290-299

Hobro, R. (1979). Annual phytoplankton successions in a coastal area in the northern Baltic. In: Naylor, E., Hartnoll, R. G. (ed.) Cyclic phenomena in marine plants and animals. Pergamon, Oxford, p. 3-10

Huttunen, M., Kuparinen, J. (1986). Species succession and productivity of ultraphytoplankton in the pelagic off Tvärminne, SW coast of Finland. Ophelia, Suppl. 4: 73-83

Jansson, B.-O., Wilmot, W., Wulff, F. (1984). Coupling the subsystems - the Baltic Sea as a case study. In: Fasham, M. J. R. (ed.) Flows of energy and materials in marine ecosystems. Plenum, New York, p. 549-595

Kahru, M., Aitsam, A. (1985). Chlorophyll variability in the Baltic Sea: a pitfall for monitoring. J. Cons. int. Explor. Mer. 42: 111-115

Kahru, M., Nômmann, S. (1990). The phytoplankton spring bloom in the Baltic Sea in 1985, 1986: multitude of spatiotemporal scales. Cont. Shelf Res. 10: 329-354

Kahru, M., Nômmann, S., Allikas, E. (1989). A measurement system for studying spatial distribution of plankton. Oceanology 29: 670-674 (in Russian)

Kahru, M., Nômmann, S., Sildam, J., Allikas, E. (1987). Monitoring the chlorophyll and phytoplankton concentrations: implications of the spatio-temporal variability. Baltic Sea Environ. Proc. 19: 465-478

Kahru, M., Nômmann, S., Simm, M., Vilbaste, K. (1986). Plankton distributions and processes in the Baltic boundary zones. In: Nihoul, J. C. J. (ed.) Marine interfaces ecohydrodynamics. Elsevier, Amsterdam, p. 273-293

Kiørboe, T., Kaas, H., Kruse, B., Møhlenberg, F., Tiselius, P., Artebjerg, G. (1990). The structure of the pelagic food web in relation to water column structure in the Skagerrak. Mar. Ecol. Prog. Ser. 59: 19-32

'Kononen, K., Niemi, A. (1986). Variation in phytoplankton and hydrography in the outer archipelago at the entrance to the Gulf of Finland in 1968-1975. Finnish mar. Res. 253: 35-51

Kuparinen, J., Leppänen, J.-M., Sarvala, J., Sundberg, A,, Virtanen, A. (1984). Production and utilization of organic matter in a Baltic ecosystem off Tvärminne, SW coast of Finland. Rapp. P.-v. Réun. Cons, int. Explor. Mer 183: 180-192

Lahdes, E., Kononen, K., Karjala, L., Leppänen, J.-M. (1988). Cycling of organic matter during the vernal growth period in the open northern Baltic Proper. V. Community respiration and bacterial ecology. Finnish mar. Res. 255: 79-95

Lahdes, E., Leppănen, J.-M. (1988). Cycling of organic matter during the vernal growth period in the open northern Baltic Proper. II. Nutrient development and chemical composition of particulate matter. Finnish mar. Res. 255: $19-35$

Larsson, U., Elmgren, R., Wulff, F. (1985). Eutrophication and the Baltic Sea: causes and consequences. Ambio 14: 9-14

Larsson, U., Hagström, A. (1982). Fractionated phytoplankton primary production, exudate release and bacterial production in a Baltic eutrophication gradient. Mar. Biol. 67: $57-70$

Leppänen, J.-M. (1988). Carbon and nitrogen cycles during 
the vernal growth period in the open northern Baltic Proper. Meri 16, Suppl.: 5-38

Malone, T. C. (1980). Algal size. In: Morris, I. (ed.) The physiological ecology of phytoplankton. Blackwell, Oxford, p. 433-463

Mayzaud, P., Taguchi, S., Laval, Ph. (1984). Seasonal patterns of seston characteristics in Bedford Basin, Nova Scotia, relative to zooplankton feeding: a multivariate approach. Limnol. Oceanogr. 29: 745-762

Niemi, A. (1975). Ecology of phytoplankton in the Tvärminne area, SW coast of Finland. Acta Bot. Fenn. 105: 1-68

Platt, T., Denman, K. L. (1978). The structure of pelagic marine ecosystems, Rapp. P.-v. Réun. Cons, int. Explor. Mer. 178: 24-27

Pugh, P. R. (1978). The application of particle counting to an understanding of the small-scale distribution of plankton.

This article was presented by Dr G. Savidge, Portaferry, N. Ireland
In: Steele, J. H. (ed.) Spatial pattern in plankton communities. Plenum, New York, p. 111-129

Sheldon, R. W., Prakash, A., Sutcliffe, W. H., Jr (1972). The size distribution of particles in the ocean. Limnol. Oceanogr. 17: 327-340

Smetacek, V., Bodungen, B. v., Knoppers, B., Peinert, R., Pollehne, F., Stegman, P., Zeitzchel, B. (1984). Seasonal stages in characterizing the annual cycle of an inshore pelagic system. Rapp. P.-v. Réun. Cons. int. Explor. Mer 183: $126-135$

Steele, J. H. (1974). The structure of marine ecosystems. Harvard Univ Press, Cambridge

Wulff, F. (1988). Understanding the Baltic Sea: systems ecology in theory and practice. In: Wolff, W., Soeder, C.-J., Drepper, F.R. (eds.) Ecodynamics - contributions to theoretical ecology. Springer, Berlin, p. 113-126

Manuscript first received: March 5, 1990

Revised version accepted: September 27, 1990 